\title{
Allergic Contact Dermatitis Among Healthcare Workers Exposed to Glutaraldehyde
}

\author{
Rita I. Wijaya ${ }^{1^{*}}$, Muhammad Ilyas ${ }^{2}$ \\ ${ }^{1}$ Occupational Medicine Specialist Program, Department of Community Medicine, Faculty of Medicine Universitas Indonesia \\ ${ }^{2}$ Division of Ocuupational Medicine, Department of Community Medicine, Faculty of Medicine Universitas Indonesia \\ ${ }^{*}$ Corresponding address: Rita Ingewaty Wijaya \\ E-mail: ritaingewatywjy@gmail.com
}

\begin{abstract}
Background: One of the health problems that can be caused by glutaralaldehyde is allergic contact dermatitis (ACD). However, the causal relationship between glutaraldehyde and DKA is still unclear, so it is necessary to look for some evidence regarding this relationship. The search for evidence is also equipped with a seven-step assessment of occupational diseases therefore it can assist occupational medicine doctors who find patients with ACD and have a history of exposure to glutaraldehyde.

Methods: Literature search using Pubmed, Scopus and JSTOR databases. The keywords used are 'healthcare worker OR healthcare personnel', 'glutaraldehyde' and 'allergic contact dermatitis. Article selection was performed using the defined inclusion and exclusion criteria. Selected articles will be critically reviewed based on etiological studies from the Oxford Center of Evidence-Based Medicine.

Result: It was in six selected articles that met the inclusion and exclusion criteria. The main finding after a critical review was that glutaraldehyde may increase the risk of ACD.

Conclusion: There is a relationship between $1 \%$ glutaraldehyde exposure and the incidence of ACD in health workers. To establish the diagnosis of occupational diseases in health workers who are exposed to glutaraldehyde, seven steps of diagnosis of occupational diseases are used.

Key words: glutaraldehyde, allergic contact dermatitis, occupational diseases
\end{abstract}

\begin{abstract}
Abstrak
Latar belakang: Salah satu masalah kesehatan yang dapat ditimbulkan oleh glutaralaldehyde adalah dermatitis kontak alergi (DKA). Tetapi hubungan sebab akibat antara glutaraldehyde dan DKA masih belum jelas sehingga untuk itu perlu dicari beberapa bukti mengenai hubungan tersebut. Pencarian bukti juga dilengkapi dengan penilaian tujuh langkah penyakit akibat kerja sehingga dapat membantu dokter kesehatan kerja yang mendapatkan pasien dengan DKA serta memiliki riwayat terpajan glutaraldehyde.

Metode: Pencarian literatur menggunakan basis data Pubmed, Scopus dan JSTOR. Kata kunci yang digunakan 'healthcare worker OR healthcare personnel', 'glutaraldehyde' and 'allergic contact dermatitis'. Pemilihan artikel dilakukan dengan menggunakan kriteria inklusi dan eksklusi yang telah ditentukan. Artikel yang terpilih akan ditelaah secara kritis berdasarkan studi etiologi dari Oxford Centre of Evidence-Based Medicine. Hasil: Didapatkan enam artikel terpilih yang memenuhi kriteria inklusi dan eksklusi. Temuan utama setelah dilakukan telaah secara kritis bahwa glutaraldehyde dapat meningkatkan risiko DKA.

Kesimpulan: Ada hubungan antara pajanan glutaraldehyde 1\% dengan kejadian DKA pada petugas kesehatan. Untuk menegakkan diagnosis penyakit akibat kerja pada petugas kesehatan yang terpapar glutaraldehid digunakan tujuh langkah diagnosis penyakit akibat kerja.

Kata kunci: glutaraldehyde, dermatitis kontak alergi, penyakit akibat kerja
\end{abstract}




\section{Introduction}

Glutaraldehyde is used for industrial, laboratory, agricultural, and medical purposes, primarily for disinfecting and sterilization of surfaces and equipment. It may be found in medical facilities where it is used to disinfect equipment that cannot be subject to heat sterilization. It is also used in industrial cleaning supplies. Glutaraldehyde as a disinfectant and sterilising agent (usually as a $2 \%$ solution) in medical and dental settings. ${ }^{1,2}$

The excellent properties of glutaraldehyde make it the first choice in hospital in terms of considerations for health and safety in the workplace. ${ }^{3}$ Hospital workers who are likely to be exposed to glutaraldehyde including workers who work in cold sterilizing procedure areas (for example, gastroenterology and cardiology departments), operating rooms, dialysis, endoscopy units, intensive care units, central sterilization, research technicians, researchers, and pharmacy personnel, laboratory technicians and workers who develop x-rays. ${ }^{3}$ Glutaraldehyde can be absorbed into the human body via oral, dermal, and inhalation routes. Glutaraldehyde is distributed via blood and oxidized into glutaric acid and metabolized to $\mathrm{CO}_{2}$ in its metabolism path. ${ }^{1,4}$ Glutaraldehyde-spesific markers have not been identified. Detection of glutaraldehyde in tissue samples or body fluids could serve as confirmation of exposure. ${ }^{5}$ Glutaraldehyde solutions may cause mild to severe irritation or sensitization to the skin, depending on the concentration of the solution and the duration of exposure/contact. ${ }^{6}$

Health issues in health workers due to glutaraldehyde exposure are known to be divided into acute and chronic. The acute stage can cause skin irritation, eye irritation, contact dermatitis, and headaches while the chronic stage can cause irritant contact dermatitis, contact dermatitis, systemic sensitization, and occupational asthma. ${ }^{4}$ In a study conducted by Eustachio Nettis et al (2002), the prevalence of ACD was $32.6 \%$, and irritant contact dermatitis (ICD) was $67.4 \%$. Atopic history was found $6.9 \%$ among those patients. The composition of atopic history was significantly higher (p 0.05) among subjects with ICD (9.6\%) compared with patients who had ACD (1.5\%) or with patients who had allergic and irritant contact dermatitis (3.9\%). This study also found that nickel sulphate, disinfectant components (glutaraldehyde and benzalkonium chloride), and rubber chemicals (thiuram mix, carba mix, and tetramethylthiuram monosulphide) were the most common causative agents inducing occupational allergy. ${ }^{7}$ The result of the patch test in a study conducted by A. Schnuch et al (1998) suggested that glutaraldehyde was the most important disinfectant allergen that significantly increases the risk of ACD in nurses, receptionists, and dental nurses. ${ }^{8}$

From the explanation given above, we know by now that there is a risk of ACD in health workers who are exposed to glutaraldehyde. However, the causal relationship between ACD and glutaraldehyde remains unclear because health workers are not only exposed to glutaraldehyde. In this review, some of the evidence implicating glutaraldehyde in causing ACD will be summarized. In addition, we will also use the seven steps of occupational diagnosis as instituted by Indonesian Occupational Medicine Specialist Association (IOMA) ${ }^{9}$, to help determine whether there is a causal relationship of a disease and work exposure.

\section{Method}

We conducted literature searches using electronic databases, that is, PubMed, Scopus and JSTOR. The keywords were 'healthcare worker OR healthcare personnel', 'glutaraldehyde' and 'allergic contact dermatitis'. The inclusion criteria were (1) respondents come from health workers; (2) intervention or exposure is glutaraldehyde; (3) study design were systematic review, meta-analysis, cohort study, case control study and cross-sectional study. The exclusion criteria were non-English articles and inaccessible articles. The search strategy is shown in a flowchart (Figure 1).

The selected literature was critically appraised using relevant criteria with the worksheet for etiology study from Oxford Centre of Evidence-Based Medicine. We used the prevalence value of allergic contact dermatitis at the $\mathrm{X}$ hospital polyclinic visit from January - July 2020 as the PEER value (2\%), with the assumption that allergic contact dermatitis in the population was not due to exposure to glutaraldehyde. 


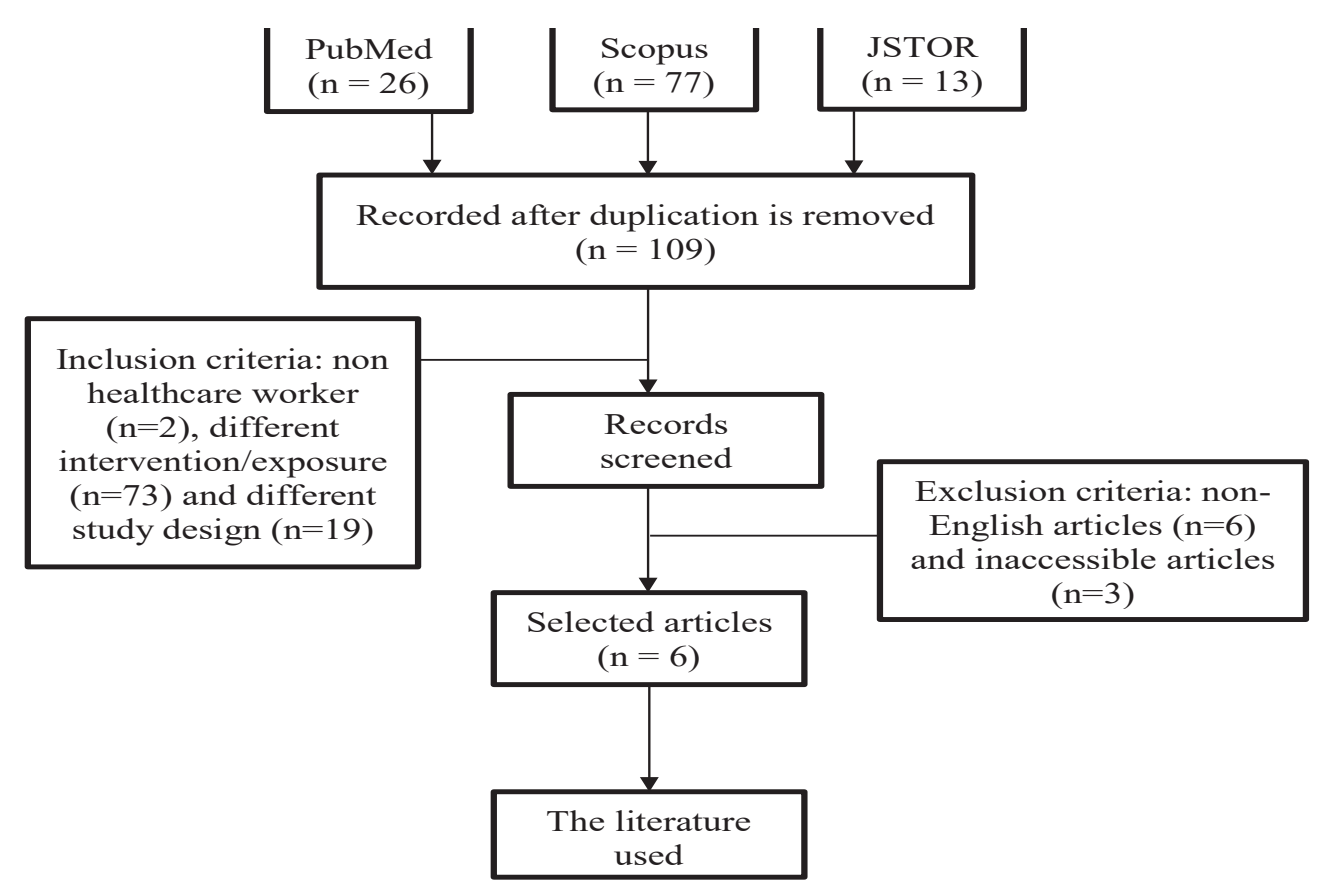

Figure 1. Flowchart of literature search

\section{Result}

The searching was completed on August $12^{\text {th }}, 2020$. Of the online searches, it resulted in six selected articles that met the inclusion and exclusion criteria. The selected articles consisted of 1 cohort study by Matthew P. S et al, 2000, 2 case control studies by Tina Suneja et al, 2008, and Salmon Kadivar BA et al, 2015, and 3 crosssectional studies by Scott M. Ravis. et al, 2003, Erin M. Warshaw et al, 2008, and Maya Lyapina et al, 2014. ${ }^{10-15}$ Critical appraisal are shown in Table 2.

After critically assessed, there was only one article conducted an observational study, namely the prospective cohort study, and it was the best study to establish a causal relationship between exposure and outcome. The article was a study conducted by Matthew P. Shaffer et $\mathrm{al}^{10}$ where the article has reliable data collection method and outcome measures, long-term and completed follow-up of the study, included the administration of gradual dosing, and even followed-up on job changes of respondents.

Meanwhile, the other five articles have limitations in determining a causal relationship due to the study design used was not suitable to determine whether the exposure happened before the outcome occurred. However, these five articles are valid enough to be used as illustrations to determine if there is any possibility of a causal relationship between glutaraldehyde exposure and the incidence of allergic contact dermatitis in healthcare workers. The validity of the articles can be assessed from the method used by each of the articles. All articles determined or divided the respondents' groups clearly and assessed the outcome and the exposure objectively using a predetermined standard, namely the patch test.

Even though Salmon Kadivar BA et $\mathrm{al}^{12}$ and Maya Lyapina et $\mathrm{al}^{15}$ were stated as valid studies, the magnitude of the relationship between glutaraldehyde and ACD is considered of no importance. This is because the study conducted by Salmon Kadivar BA et $\mathrm{al}^{12}$ could not be assessed for the magnitude even though it was statistically significant, while a study conducted by Scott M. Ravis et $\mathrm{al}^{13}$ found that the relationship is insignificant. Hence, it is not possible to determine how potential the glutaraldehyde to increase the risk of ACD. 
Tabel 1. The Critical Appraisal of The Study

\begin{tabular}{|c|c|c|c|c|c|c|}
\hline Question & Article 1 & Article 2 & Article 3 & Article 4 & Article 5 & Article 6 \\
\hline \multicolumn{7}{|l|}{ Is the result of this harm study valid? } \\
\hline $\begin{array}{l}\text { Were there clearly defined groups of } \\
\text { patients, similar in all important ways } \\
\text { other than exposure to the treatment } \\
\text { or other cause? }\end{array}$ & Yes & Yes & Yes & Yes & Yes & Yes \\
\hline $\begin{array}{l}\text { Were treatments/exposures and } \\
\text { clinical outcomes measured in the } \\
\text { same ways in both groups (was } \\
\text { the assessment of outcomes either } \\
\text { objective or blinded to exposure)? }\end{array}$ & Yes & Yes & Yes & Yes & Yes & Yes \\
\hline $\begin{array}{l}\text { Was the follow-up of study patients } \\
\text { sufficiently long and complete? }\end{array}$ & Yes & Yes & No & No & No & No \\
\hline \multicolumn{7}{|c|}{ Do the results satisfy some "diagnostic tests for causation"? } \\
\hline $\begin{array}{l}\text { Is it clear that the exposure preceded } \\
\text { the onset of the outcome? }\end{array}$ & Yes & No & No & No & No & No \\
\hline Is there a dose-response gradient? & Yes & No & No & Yes & No & No \\
\hline $\begin{array}{l}\text { Is there positive evidence from a } \\
\text { "dechallenge-rechallenge" study? }\end{array}$ & Yes & No & No & No & No & No \\
\hline $\begin{array}{l}\text { Is the association consistent from } \\
\text { study to study? }\end{array}$ & No & Yes & No & No & Yes & No \\
\hline $\begin{array}{l}\text { Does the association make biological } \\
\text { sense? }\end{array}$ & Yes & Yes & Yes & Yes & Yes & Yes \\
\hline
\end{tabular}

Tabel 2. The Critical Appraisal of The Study (continued)

\begin{tabular}{|c|c|c|c|c|c|c|}
\hline Question & Article 1 & Article 2 & Article 3 & Article 4 & Article 5 & Article 6 \\
\hline \multicolumn{7}{|c|}{ Are the valid results from this harm study important? } \\
\hline $\begin{array}{l}\text { What is the magnitude of the } \\
\text { association between the exposure } \\
\text { and outcome? }\end{array}$ & $\begin{array}{c}\text { RR } 5.77 \\
(\mathrm{p}<0.001)\end{array}$ & $\begin{array}{c}\text { RR 9 } \\
(p<0.001)\end{array}$ & - & $\begin{array}{l}\text { RR } 1.42 \\
(\mathrm{p} 0.02)\end{array}$ & $\begin{array}{l}\text { RR } 9.75 \\
(\mathrm{p}<0.001)\end{array}$ & - \\
\hline $\begin{array}{l}\text { What is the precision of the estimate } \\
\text { of the association between exposure } \\
\text { and outcome? }\end{array}$ & $\begin{array}{c}95 \% \text { CI } \\
5.58-6.44\end{array}$ & $\begin{array}{c}95 \% \text { CI } \\
9.21-9.75\end{array}$ & - & $\begin{array}{c}95 \% \text { CI } \\
1.33-1.97\end{array}$ & $\begin{array}{c}95 \% \mathrm{CI} \\
9.15-10.55\end{array}$ & - \\
\hline \multicolumn{7}{|c|}{ Should these valid, potentially important results change the treatment of your patient? } \\
\hline Do the results apply to our patient? & Yes & Yes & No & Yes & Yes & No \\
\hline $\begin{array}{l}\text { Is our patient so different from } \\
\text { those in the study that its results } \\
\text { don't apply? }\end{array}$ & No & No & - & No & No & - \\
\hline $\begin{array}{l}\text { What are our patient's risks of the } \\
\text { adverse event? }\end{array}$ & PEER $=0.02$ & PEER $=0.02$ & - & PEER $=0.02$ & PEER $=0.02$ & - \\
\hline $\begin{array}{l}\text { To calculate the NNH (number of } \\
\text { patients we need to treat to harm one } \\
\text { of them for any odds ratio (OR) and } \\
\text { our patient's expected event rate for } \\
\text { this adverse event if they were not } \\
\text { exposed to this treatment (PEER): } \\
\text { NNH }=\frac{P E E R(\mathbb{Q}-1)+1}{\text { PEER }(\boldsymbol{Q}-1) \times(1-\text { PEER })}\end{array}$ & $\mathrm{NNH}=12$ & $\mathrm{NNH}=7$ & & $\mathrm{NNH}=126$ & $\mathrm{NNH}=7$ & \\
\hline
\end{tabular}




\section{Discussion}

We used the seven steps of occupational diagnosis as instituted by IOMA ${ }^{9}$ in order to determine the relationship between diseases with workers if we found that the workers are with allergic contact dermatitis exposed to glutaraldehyde.

The first step is to determine the clinical diagnosis. ACD can be diagnosed by history taking, and physical examination. History-taking reveals a symptom of intense pruritus and a history of exposure to allergen substances. ${ }^{16}$ Physical examination finds spreading reactions, moving outwards from the primary site of exposure. In the acute phase, physical findings consist of erythema, oedema, papules, vesicules, and oozing followed by crusting, while in the chronic phase, it would be lichenified, fissured and pigmented. ${ }^{17-19}$

The second step was determine exposure in the workplace or work environment. All physical, chemical, biological, ergonomics, and psychosocial hazards in the workplace that potentially causes occupational disease or increases the risk of occupational disease must be listed. In this case, glutaraldehyde has the risk to develop ACD will be investigated. Details are needed from the company, its products, the material used for the process, worksite, job description, and use of protective devices and equipment while working. The history-taking needs to include a complete job of anamneses, which includes a description of all the work in chronological order such as the period of time doing each job, what the resulting product is, the material used, and how it works. It is better to be guided by MSDS (Material Safety Data Sheet) of material used.

The third step was determining whether there is a relationship between exposure to the disease. Make sure to identify any exposure-related disease. This relationship should be based on the result of previous epidemiological studies (evidence-based). To identify whether or not there is a relationship between glutaraldehyde and ACD, can be done by reviewing existing literature or references and applying Bradford Hill's Criteria:

1. Strength of association

Of the 6 appraised articles, 4 articles suggested a significant relationship between glutaraldehyde and ACD, namely a study conducted by Matthew P. Shaffer et $\mathrm{al}^{10}$ with RR 5.77 (95\% CI 5.58 - 6.44, p < 0.001), Tina
Suneja et $\mathrm{al}^{11}$ RR 9 (95\% CI 9.21 - 9.75, p < 0.001), Scott M. Ravis et a ${ }^{13}$ RR 1.42 (95\% CI 1.33 - 1.97, p 0.02), and Erin M. Warshaw et $\mathrm{al}^{14} \mathrm{RR} 9.75$ (95\% CI $\left.9.15-10.55, \mathrm{p}<0.001\right)$. The confidence interval of a study conducted by Salmon Kadivar BA et al ${ }^{12}$ could not be assessed statistically, even though it suggested that glutaraldehyde exposure was statistically significant as an allergen that caused allergic reactions in health workers $(\mathrm{p}<0.001)$. Maya Lyapina et $\mathrm{al}^{15}$ found no significant association between glutaraldehyde exposure and allergic contact dermatitis in dental professionals $(p$ 0.707 ) compared to formaldehyde OR 3,314 (95\% CI 1.191-9.218, p 0.019) which could be due to the glutaraldehyde dose used in the study was a low dose of $0.2 \%$ pet which might not provide sensitization the respondent.

2. Consistency

The results of 4 out of 6 articles consistently stated that glutaraldehyde causes ACD while one article can not be assessed because there is no magnitude association value and another one article found that glutaraldehyde did not significantly associate with ACD.

3. Specificity

Of 6 articles, Matthew P. Shaffer et $\mathrm{al}^{10}$ Salmon Kadivar BA et $\mathrm{al}^{12}$ and Scott M. Ravis et $\mathrm{al}^{13}$, stated that atopic status did not statistically affect the incidence of ACD on glutaraldehyde exposure. Tina Suneja et $\mathrm{al}^{11}$ stated that atopic status influenced the increasing problem of ACD, while Erin M. Warshaw et $\mathrm{l}^{14}$ and Maya Lyapina et $\mathrm{al}^{15}$ stated that atopic history has the highest proportion in workers who were diagnosed with ACD.

4. Temporality

Matthew P. Shaffer et $\mathrm{al}^{10}$ followed the subjects for 5 years and obtained new cases of allergic contact dermatitis due to glutaraldehyde among healthcare workers. The new cases were as follows: 0 in 1994; 2 in 1995; 2 in 1996; 1 in 1997; 4 in 1998. Meanwhile, the other five articles did not follow their subjects for a certain period of time.

5. Biological gradient (dose-response) In the studies conducted by Matthew P. Shaffer et $\mathrm{al}^{10}$ and Scott M. Ravis et $\mathrm{al}^{13}$, each subject was given 3 different doses of glutaraldehyde, 
$0.2 \%, 0.5 \%$ and $1 \%$ in petrolatum. In article 1 , it is clearly stated that by administering a glutaraldehyde dose of $0.2 \%$, four people were diagnosed with ACD, and at a dose of $0.5 \%$, five people were diagnosed with ACD. Meanwhile, Scott M. Ravis et $\mathrm{al}^{13}$ did not mention such a division.

6. Biological Plausability

In experiments with pigs, the concentration for glutaraldehyde in aqueous solution to induce dermal sensitization is within the range of 0.1 to $1.0 \%{ }^{6}$

7. Coherence

Of six articles, the assessment of ACD uses a patch test where the patch test is one of the diagnostic tests to diagnose of ACD due to certain allergens. ${ }^{16,17}$

8. Reversibility (experimental evidence) Matthew P. Shaffer et a $\mathbf{l}^{10}$ glutaraldehyde has many toxic side-effects, including the ability to induce allergic contact dermatitis. In a 5-year study at the University of Kansas, 468 patients were patch tested to glutaraldehyde. A comparison of results was made between those employed in a health-care related field and those who were not. Health-care workers (HCWs was to target to follow-up nine subjects identified with ACD. Of the nine targeted to follow-up subjects, three subjects were unfollowable, three subjects had changed their occupation and had their dermatitis improved, and the remaining three subjects did not change their jobs. However, two of the latter avoided glutaraldehyde and had their dermatitis improved, while the remaining one person did not. Nevertheless, some of these subjects were also exposed to other chemicals in the workplace.

9. Analogy

Glutaraldehyde does not specifically cause ACD only and vice versa. ACD is not specifically because of the glutaraldehyde alone. As stated in the 6 appraised articles, health workers were also exposed to other chemicals that gave ACD reactions with a patch test.

The fourth step was to determine whether the exposure is sufficient. In sensitized patients, ACD occurs 24 to 96 hours after contact with the agent. ${ }^{17,18}$ Tina Suneja et $\mathrm{al}^{11}$, Salmon Kadivar BA et $\mathrm{al}^{12}$, Scott M. Ravis et $\mathrm{al}^{13}$, Erin M. Warshaw et $\mathrm{al}^{14}$, Maya Lyapina et a ${ }^{15}$ the results of the patch test examined between the second and fourth days have shown results. Matthew P. Shaffer et $\mathrm{al}^{10}$ required a longer time (1-4 years) and increased dose to show that glutaraldehyde can cause ACD.

The fifth step was to determine if any individual factors that play a role. Of six articles, three articles stated that atopic status did not statistically affect the incidence of ACD on glutaraldehyde exposure. Meanwhile, the other three articles stated that there was an influence atopic status on the incidence of ACD.

The sixth step was to determine whether there are other factors outside work. Whether there is any exposure to glutaraldehyde outside of work such as side jobs that require the use of a disinfectant, or the use of daily products contained with glutaraldehyde. Disinfectants containing glutaraldehyde are still sold over-the-counter, not only sold for the necessity of company but also in forms of products such as fly and insect repellent whose chemicals contain glutaraldehyde which also found in one of the brands in Indonesia.

The seventh step was to determine the occupational diagnosis. If steps 2,3 , and 4 are appropriate, and there is no factor outside of work, then ACD is an occupational disease.

\section{Conclusion}

To determine the causal relationship, we conducted critical appraisal using the Evidence-Based Medicine etiology study worksheet and Austin Bradford Hill's criteria, which suggested a relationship between the use of a disinfectant containing 1\% glutaraldehyde and the incidence of ACD in healthcare workers. This causal relationship also suggests that individual factors such as atopic history does not predispose a person to develop allergic contact dermatitis due to glutaraldehyde exposure. To establish an occupational diagnosis in healthcare workers exposed to glutaraldehyde, we can use seven steps of occupational disease diagnosis - from the first step of determining clinical diagnosis to the step of determining whether there are other factors outside of work considering glutaraldehyde can still be found on the market.

After all, we recommend, hospitals or health services still using glutaraldehyde products as a disinfectant will surely need to know more about the health effects of 
glutaraldehyde exposure upon their workers. Implement appropriate controls of technique, administration, and personal protective equipment (PPE) to reduce such glutaraldehyde exposure. In addition, further research is needed to evaluate the number of glutaraldehyde doses $(0.2 \%, 0.5 \%, 1.0 \%$ in petrolatum) associated with the length of work of healthcare workers exposed to glutaraldehyde.

\section{References}

1. Toxicological Profiles |ATSDR [Internet]. Available from: https://www.atsdr.cdc.gov/toxprofiledocs/index. html?id=1467\&tid $=284$.

2. Glutaraldehyde | C5H8O2 - PubChem [Internet]. Available from: https://pubchem.ncbi.nlm.nih.gov/compound/3485

3. Glutaraldehyde | NIOSH | CDC [Internet]. [cited 2021 Sep 29]. Available from: https://www.cdc.gov/niosh/topics/ glutaraldehyde/.

4. Smith DR, Wang R-S. Glutaraldehyde exposure and its occupational impact in the health care environment. Environ Health Prev Med. 2006;11(1).

5. Atsdr. Glutaraldehyde ToxGuide. Available from: www.atsdr. cdc.gov

6. Shanahan EM. Glutaraldehyde. 2014;(October 1992).

7. Nettis E, Colanardi MC, Soccio AL, Ferrannini A, Tursi A. Occupational irritant and allergic contact dermatitis among healthcare workers. Contact Dermatitis. 2002;46(2):101-7.

8. Schnuch A, Uter W, Geier J, Frosch PJ, Rustemeyer T. Contact allergies in healthcare workers. Results from the IVDK. Acta Derm Venereol. 1998;78(5):358-63.
9. Indonesia PSK. Pedoman Klinis Diagnosis dan Tatalaksana Kasus Penyakit Akibat Kerja.

10. Shaffer MP, Belsito D V. Allergic contact dermatitis from glutaraldehyde in health-care workers. Contact Dermatitis. 2000;43(3):150-6.

11. Suneja T, Belsito D V. Occupational dermatoses in health care workers evaluated for suspected allergic contact dermatitis. Contact Dermatitis. 2008;58(5):285-90.

12. Kadivar S, Belsito D V. Occupational Dermatitis in Health Care Workers Evaluated for Suspected Allergic Contact Dermatitis. Dermatitis. 2015;26(4):177-83.

13. Ravis SM, Shaffer MP, Shaffer CL, Dehkhaghani S, Belsito D V. Glutaraldehyde-induced and formaldehyde-induced allergic contact dermatitis among dental hygienists and assistants. J Am Dent Assoc. 2003;134(8):1072-8.

14. Warshaw EM, Schram SE, Maibach HI, Belsito D V., Marks JG, Fowler JF, et al. Occupation-related contact dermatitis in North American health care workers referred for patch testing: Cross-sectional data, 1998 to 2004. Dermatitis. 2008;19(5):261-74.

15. Lyapina M, Krasteva A, Dencheva M, Tzekova M, Deliverska M, Kisselova-Yaneva A. Comparative overall health status assessment of subjects with allergic contact dermatitis to formaldehyde and glutaraldehyde. Biotechnol Biotechnol Equip. 2013;27(6):4297-303.

16. Brasch J, Becker D, Aberer W, Bircher A, Kränke B, Jung K, et al. Guideline Contact Dermatitis. Allergo J. 2014;23(4):30-43.

17. Johansen JD, Aalto-Korte K, Agner T, Andersen KE, Bircher A, Bruze M, et al. European Society of Contact Dermatitis guideline for diagnostic patch testing - Recommendations on best practice. Contact Dermatitis. 2015;73(4):195-221.

18. Nicolas J. Pathophysiology of Allergic and Irritant Contact Dermatitis. 2012; (August 2017).

19. Dokter Spesialis B. PANDUAN PRAKTIK KLINIS. 2017. 